загальнонаукових компетенцій, як за спорідненими напрямами підготовки. У зв’язку з цим навчання фізики бакалаврів 3 комп'ютерної інженерії повинно бути спрямованим на формування професійних виробничих функцій майбутнього фахівця, провідними 3 яких $є$ проектувальна (насамперед із розроблення програмних та комп'ютерних компонентів) та дослідницька (насамперед з комп’ютерного моделювання). Це створює умови для залучення до процесу навчання фізики засобів IKT, що надають можливість створення й дослідження комп’ютерних моделей фізичних процесів.

\title{
Література
}

1. Інформаційна система «Конкурс» [Електронний ресурс]/ Міністерство освіти і науки України, ГО «Центр освітньої політики». - 2008-2015. - Режим доступу : http://vstup.info. 2. Національний класифікатор України «Класифікація видів економічної діяльності» (КВЕД). ДК 009 : 2005 [Текст] : станом на 10 груд. 2010 р. - Київ : Центр учбової л-ри : ВМГО «Укр. молодіж. правничий союз», 2011. - 223, [1] с. 3. Національний класифікатор України «Класифікатор професій» ДК 003 : 2010. Станом на 11.04.2011 р.Київ : Центр учбової літератури, 2011. - 360 с. 4. Освітньо-кваліфікаційна характеристика бакалавра. Галузь знань 0501 «Інформатика та обчислювальна техніка». Напрям підготовки 6.050102 «Комп’ютерна інженерія». - Офіц. вид. - Київ : Міністерство освіти і науки, молоді та спорту України, 2011.- (Галузевий стандарт вищої освіти України). 5. Освітньопрофесійна програма бакалавра. Галузь знань 0501 «Інформатика та обчислювальна техніка». Напрям підготовки 6.050102 «Комп’ютерна інженерія». - Офіц. вид. - Київ : Міністерство освіти і науки, молоді та спорту України, 2011. - (Галузевий стандарт вищої освіти України).

Микола Стрюк

\section{ТЕНДЕНЦІЇ РОЗВИТКУ МОБІЛЬНОСТІ СТУДЕНТІВ ТА МОЛОДИХ НАУКОВЦІВ У ЄВРОПЕЙСЬКОМУ ОСВІТНЬО-НАУКОВОМУ ПРОСТОРІ}

Стрюк М. І. Тенденції розвитку мобільності студентів та молодих науковців у європейському освітньо-науковому просторі.

У статті виокремлено нові напрями реалізації мобільності студентів, аспірантів та викладачів у Європейському освітньо-науковому просторі, застосування яких в Україні сприятиме підвищенню конкурентоздатності вітчизняної системи освіти. Особливу увагу приділено шляхам розв’язання проблеми «витоку мізків».

Ключові слова: академічна мобільність, мобільність студентів та аспірантів, програми мобільності, постачальники мобільності, віртуальна мобільність, «витік мізків».

Стрюк Н. И. Тенденции развития мобильности студентов и молодых ученых в европейском образовательно-научном пространстве.

В статье выделены новые направления реализации мобильности студентов, аспирантов и преподавателей в Европейском образовательно-научном пространстве, применение которых в Украине будет способствовать повышению конкурентоспособности отечественной системы образования. Особое внимание уделено путям решения проблемы «утечки мозгов».

Ключевые слова: академическая мобильность, мобильность студентов и аспирантов, программы мобильности, поставщики мобильности, виртуальная мобильность, «утечка мозгов». 
Stryuk M. I. Trends in mobility of students and young scientists in the European educational and scientific area.

The article highlights the new directions of the mobility of students, postgraduates and professors in the European educational and scientific are, the use of which in Ukraine will increase the competitiveness of the national education system. Particular attention is devoted to ways of solving the problem of brain drain.

Key words: academic mobility, mobility of students and postgraduates, mobility programs, suppliers of mobility, virtual mobility, brain drain.

Мобільність освіти є принциповою характеристикою єдиного освітнього простору, на формування якого спрямований, зокрема, й Болонський процес: достатньо констатувати принципи Великої хартії університетів [15], в тому числі четвертий принцип - принцип мобільності, що розуміється в найширшому сенсі- мобільність знання. Його реалізація в академічній мобільності (можливості для студентів та викладачів переміщатися між різними освітніми установами всередині і за межами своєї країни) із самого початку була тісно пов'язана із соціальною та професійною мобільністю: так, Е. Девіс (Allison Davis) та Дж. Доллард (John Dollard) у 1940 р. розглядали iї у контексті особистісного розвитку негритянської молоді у містах американського півдня [5, с. 57]. Е. Ко (Edmond Ко) уводить поняття студентської мобільності як здатності студентів навчатися або працювати після завершення навчання у ВНЗ, перетинаючи національні кордони [11, с. 209]. Дослідник підкреслює, що важливим наслідком глобалізації є підвищення мобільності студентів, вступників та випускників університетів: особа, що має високий рівень мобільності, можете вчитися (бути академічно мобільною), працювати (бути географічно та професійно мобільною), співпрацювати та бути конкурентоздатною в будь-якій країні. Важливим наслідком цього є зростання необхідності уведення міжнародних норм і стандартів, за допомогою яких академічні кваліфікації з різних країн можуть бути порівняні та визнані. Крім цього, ураховуючи тенденцію до навчання протягом усього життя, необхідним є також міжнародне унормування дистанційного навчання, підготовки, перепідготовки, підвищення кваліфікації тощо. Виникнення навчальної мобільності було пов’язано із розвитком засобів та методів навчання осіб із особливими потребами [13, с. 186]. Так, типовими послугами із забезпечення навчальної мобільності, що надаються студентам 3 порушеннями зору, $\epsilon$ досягнення систематичної орієнтації і безпечного пересування у середовищі ВН3, вдома і у спільноті через використання інформації, отриманої за допомогою органів чуття (наприклад, звук, температура і вібрація) для встановлення, підтримки або відновлення орієнтації, та відповідних концепцій, методів та інструментів [12, с. 836]. Нині навчальна мобільність розглядається насамперед як короткотермінова академічна мобільність.

У статті автора [16] на основі нових історико-педагогічних джерел було досліджено витоки мобільного навчання у країнах Європейського Союзу та встановлено співвідношення різних видів мобільності (соціальної, географічної, професійної, академічної та ін.) у соціально-педагогічних системах. Метою цієї статmі є виокремлення нових напрямів реалізації мобільності студентів, аспірантів та викладачів у Європейському освітньонауковому просторі, застосування яких в Україні сприятиме підвищенню конкурентоздатності вітчизняної системи освіти.

Сприятливим для академічної мобільності є створення та поширення філій вищих навчальних закладів за межами країни, що сприяє досягненню мобільності постачальників освітніх послуг, освітніх проектів, навчальних програм та матеріалів тощо за допомогою 
таких нових форм, як комерційна концесія (франчайзинг), спільні ступені та партнерська співпраця (державна/приватна, некомерційна/комерційна, місцева/іноземна, установ/корпорацій). Нові типи партнерств формуються у відповідь на зростаючий попит на доступ до вищої освіти, а в багатьох випадках - здобуття іноземної академічної кваліфікації.

У розвитку академічної мобільності Дж. Найт (Jane Knight) виокремлює важливі тенденції. Перша тенденція - зміщення від мобільності студентів до програм i постачальників мобільності. Важливо відзначити, що кількість студентів, які прагнуть отримати освіту в зарубіжних країнах, як і раніше, зростає, але на сучасному етапі більше уваги приділяється доставлянню іноземних академічних курсів і програм студентам у їх рідній країні. Друга тенденція - зміщення орієнтації від співробітництва в цілях розвитку до конкурентоспроможної торгівлі [10, с. 510].

До нових програм мобільності Дж. Найт відносить [9, с. 383]:

- франчайзинг (franchise) - угода, за якою постачальник в країні-джерелі дозволяє постачальникові з іншої країни доставити у неї свій курс/програми/послуги;

- подвоєння (twinning) - тип транснаціональної освіти, в якому студент частину часу навчається у місцевому ВН3, а частину - у зарубіжних установах, пов'язаних із місцевим ВН3;

- подвійні/сnільні ступені (double/joint degree) - тип освіти, за якого постачальники в різних країнах співпрацюють, дозволяючи студентам програму набирати кредити у кожного постачальника з метою отримання кваліфікації від кожного з них;

- поєднання (articulation) - тип освіти, що базується на домовленості між постачальниками, розташованими у різних країнах, що надають можливість студентам набрати кредити за узгодженими курсами/програмами, спільно пропонованими всіма постачальниками;

- нострифікація (validation) - домовленість між постачальниками у різних країнах, що дозволяють постачальнику у приймаючій країні присудити кваліфікацію постачальника у країні-джерелі.

- віртуальна/дистанційна (virtual/distance) - угода, за якими постачальники поставляють курси/програми для студентів у різних країнах у дистанційному та онлайн-режимі.

Постачальники мобільності можуть бути описані через фізичне або віртуальне переміщення навчального закладу (установи, організації, підприємства) через державні кордони з метою надання освітніх послуг студентам інших країн. На відміну від програм мобільності, постачальники мобільності не вимагають фізичного переміщення студентів. Кредити та кваліфікації присвоюються іноземним постачальником (іноземні, місцеві, власні) або афілійованих місцевим партнером. До основних видів постачальників мобільності відносяться [9, с. 385]:

- філія - закордонний постачальник створює в іншій країні свою філію, надаючи студентам іншої країни свої курси і програми та присуджуючи власну кваліфікацію;

- автономна установа - іноземний постачальник (університет, компанія, або альянс/мережа) створює в іншій країні автономний ВНЗ, який не має батьківського у країні постачальника, що пропонує курси/програми і присуджує кваліфікацію;

- придбання/злиття - іноземний постачальник купує частину або 100 \% місцевого ВНЗ;

- навчальний центр/навчальний сайт - іноземний постачальник організує навчальний центр у іншій країні (що співпрацює з місцевими постачальниками або є незалежним від 
них) для підтримки студентів з опанування їх курсів/програм;

- аффіліація/мережі - різні види державних і приватних, традиційних і нових, місцевих та іноземних постачальників, що співпрацюють у рамках інноваційних типів партнерств щодо створення мереж/установ із доставляння курсів i програм місцевим i зарубіжним студентам у традиційний або дистанційний спосіб.

- віртуальний університет - постачальник, який надає освітні послуги студентам у різних країнах за допомогою дистанційної освіти з використанням переважно Інтернеттехнологій, як правило, без підтримки очного навчання.

M. ван дер Венде (Marijk van der Wende) наголошує, що віртуальні програми мобільності та віртуальні університети сьогодні $€$ основою віртуальної мобільності студентів, що базується на використанні нових IKT у вищій освіті, насамперед - Інтернет та мобільних навчальних середовищ [14]. Електронне навчання (e-learning) розширює глобальний доступ до вищої освіти, спонукаючи до педагогічних інновацій та зниженню вартості навчання. Сьогодні віртуальні університети та комбіноване навчання складають серйозну конкуренцію традиційним університетам та очному навчанню.

C. Авведуто (Sveva Avveduto) [2, с. 286], характеризуючи мобільність аспірантів та науковців, підкреслює, що мобільність висококваліфікованих фахівців може розглядатися 3 різних точок зору: як політичне питання витоку/притоку людських ресурсів («витік мізків»); проблема справедливості розподілу людських ресурсів між регіонами, що перебувають на різних рівнях розвитку; проблема політики міграції та ін.

Людські ресурси є важливим елементом суспільно-економічного розвитку, і всі інвестиції в їх освіту і доцільне використання уважаються необхідними для загального благополуччя суспільства й економіки.

У цьому контексті інтернаціоналізація освіти та науки є основними компонентами, що сприяють розвитку найкращої робочої сили - робочої сили, що займається дослідженнями у галузі науки та технологій, що складається насамперед з аспірантів та науковців, для яких мобільність $є$ ефективним засобом поширення та взаємопроникнення знань і технологій.

Межа між мобільністю та міграцією для висококваліфікованих фахівців часто стає менш очевидною. С. Авведуто вважає, що у глобалізованому суспільстві недоречно ототожнювати мобільність аспірантів і науковців із їх прагненням вирватися із країни походження: швидше за все слід розуміти ії як вільне пересування людей та ідей, а не як «перетікання» інтелекту.

Необхідність конкурувати, співпрацювати і працювати 3 іншими науковцями $\epsilon$ органічною властивістю науково-дослідної діяльності. Четвертим принципом Великої Хартії Університетів [15], підписанням якої у 1988 р. розпочався Болонський процес, є наступний: «Університет $\epsilon$ хоронителем традицій європейського гуманізму. У здійсненні свого покликання він постійно прагне до досягнення універсального знання, перетинає географічні i політичні кордони і затверджує нагальну потребу взаємного пізнання і взаємодії різних культур». Для досягнення цієї цілі вимагаються ефективні засоби, що відповідають теперішнім умовам: «Університети, особливо європейські, розглядають взаємний обмін інформацією і документацією, а також збільшення кількості спільних проектів для розвитку освіти, як основний елемент постійного прогресу знань. Тому, як і в ранні періоди своєї історії, вони стимулюють мобільність викладачів і студентів, а також розглядають загальну політику в питанні рівного статусу, звань, іспитів (без упередженого ставлення до національних дипломів) і присудження стипендій як необхідний інструмент для здійснення своєї місії». 
Європейські університети відіграють вирішальну роль у просуванні академічної мобільності. Кожен університет має власні стратегії і програми вищої і післявузівської освіти, пропонуючи висококваліфікованим членам академічної спільноти багато видів мобільності: від короткострокової відпустки до цілорічного тимчасового працевлаштування. Питання в тому, щоб визначити оптимальну частку мобільності в кар’єрі, в навчальному закладі або у країні. Якщо ця частка перевищена або не досягнула оптимальної її величини, можуть виникнути проблеми. Надлишок мобільності може викликати менше проблем, ніж його відсутність.

За даними Ж.-К. Дюмона (Jean-Christophe Dumont) та Ж. Леметра (Georges Lemaître) [6, с. 13], найбільш привабливими для іммігрантів 3 інших країн $є$ Австрія, Франція, Німеччина, Іспанія, Чехія, Швеція, Великобританія, Бельгія, Греція, Португалія, Люксембург та Нідерланди. Найбільша кількість емігрантів виїжджає з Польщі, Ірландії, Фінляндії та Угорщини. У таких країнах, як Великобританія, Німеччина та Франція, спостерігається значна еміграція на тлі ще більшої імміграції, що свідчить про надвисоку мобільність фахівців з вищою освітою.

Звичайно, немає стандартного інструменту, який може допомогти у визначенні обсягу оптимального рівня мобільності. Проте, аналіз позитивних і негативних наслідків мобільності може допомогти у виборі правильного балансу. На індивідуальному, інституційному або країновому рівні переваги наявності мобільної висококваліфікованої робочої сили і співробітництва, вивчення і досвід роботи в іншому середовищі 3 зарубіжними партнерами, досить очевидні і позитивні можливості цього досвіду говорять самі за себе. Ризики пов’язані переважно з відсутністю можливості повною мірою розвивати позитивні сторони цього досвіду або зміни характеру мобільності - від тимчасового досвіду до постійного стану мобільності.

Проведене у 2003 році опитування науковців країн Європейського Союзу [2, с. 290] показало, що провідними чинниками мобільності є кар’єрне зростання (88 \% опитаних); репутація роботодавця (74\%); доступ до передових технологій (73\%); фінансування науково-дослідних та дослідно-конструкторських робіт (70 \%); професійна мережа (68 \%); можливості трудової/підприємницької діяльності (56\%); зарплата (54\%); пригоди (49 \%); освіта (46\%).

Мобільність науковців та аспірантів як явище має свої корені у середні віки. Найперші ознаки мобільності в середньовіччі можна знайти в університетських студентів, відомі як clerici vagantes (мандрівні студенти, колишні студенти та навіть професори), і вони користувалися можливостями для переміщення всередині і за межами країни, щоб відвідати кращі університети, кожен з яких мав свою спеціалізацію, де студентська еліта могла знайти кращі знання та кращих учителів: у Болонському університеті - першу юридичну школу середньовічної Європи, у Паризькому університеті- факультети вільних мистецтв, канонічного права, медицини та теології. Багато чого, якщо не все, з тих пір змінилося, але суть мобільності полягає в переміщенні з метою знайти найкращі варіанти праці і навчання, ознайомитися з новими способами мислення, зіставити з іншими культурами та ідеями, а також зрозуміти, що відбувається за межами власного інтелектуального середовища.

У Новий час мобільність висококваліфікованих кадрів виявляється в різних формах і $з$ різною інтенсивністю, починаючи з середини XIX століття і поширюється на початку XX століття, коли наука і наукова кар’єра набувають належного рівня. Зростає кількість елітних мігрантів, у тому числі фахівців та вчених, які залишили свої країни для того, щоб почати новий бізнес або вести культурну та наукову діяльність, важливу для ряду країн та галузей 
промисловості- у фірмах, науково-дослідних лабораторіях та університетах. Міграція зростала під впливом багатьох чинників, у тому числі до і під час Другої світової війни через політичні або расові переслідування. За таких умов, наприклад, багато вчених змушені були мігрувати в США з Європи. У цьому випадку доцільно використовувати термін «витік мізків», а не мобільність. Зауважимо, що й на теперішній час серед країн-членів Організації економічного співробітництва та розвитку (OECD) найбільш привабливими для учених $\epsilon$ США та Канада.

Проведений OECD у червні 2013 р. аналіз чинників, що сприяють мобільності вчених та аспірантів, дозволив виокремити основні три чинники мобільності: академічні чинники (міграція - 43,9 \%, повернення - 27,5\%), інші чинники, пов'язані 3 роботою та працевлаштуванням (міграція - 30.9\%, повернення - 23,6\%), та сімейні або особисті причини (міграція - 15 \%, повернення - 20,6\%) [1, с. 40]. У країнах Європейського Союзу найбільший вплив академічних факторів на виїзд учених та аспірантів з Португалії (64,1\%), Іспанії $(54,1 \%)$ та Мальти (46,6\%), а найчастіше повертаються науковці та аспіранти у Болгарію (58,7\%), Португалію (39,1\%) та Угорщину (39,0 \%).

Отже, «витік мізків» можна схарактеризувати як перевищення виїзду над поверненням. У його сучасному розумінні термін «витік мізків» з’явився наприкінці 1950x pp. і був використаний в офіційному документі Королівського товариства в 1963 р. для пояснення відтоку британських науковців з країни [7]. Це поняття відноситься до надлишку сукупності талановитих людей, які змушені покинути свою країну, щоб знайти кращі умови наукової праці. Як зазначають Л. Оріоль (Laudeline Auriol), M. Micy (Max Misu) та P. А. Фріман (Rebecca A. Freeman) [1, с. 29], рівень задоволеності зарплатою та пільгами у більшості країн $є$ найнижчим. Середній рівень задоволеності стосується місця роботи, ступеня незалежності, інтелектуальної привабливості, рівня відповідальності, суспільної корисності та безпеки праці.

Мобільність аспірантів і вчених $є$ в основному їх особистим вибором (можливість отримати досвід роботи за кордоном часто розглядається і сприймається як студентами, так і викладачами, як цінність сама по собі), але може заохочуватися державними та міждержавними програмами і угодами, спрямованими на сприяння обміну дослідниками, адже у даний час підвищена мобільність уважається одним із показників здорової та інноваційної системи вищої освіти і науки. «Зелена книга» Єврокомісії «Європейський дослідницький простір» стверджує, що і уряди, і установи повинні сприяти національній та міжнародній мобільності аспірантів і науковців як найважливішого елемента Європейського дослідницького простору (ERA - European Research Area) - об'єднання наукового співтовариства, бізнесу та громадян, що має такі характеристики:

- адекватний потік компетентних дослідників із високим рівнем мобільності між установами, галузями науки та виробництва, країнами;

- дослідницька інфраструктура світового рівня, інтегрована, мережева та доступна для дослідницьких груп з різних країн Європи та світу, зокрема завдяки новому поколінню електронних комунікаційних інфраструктур;

- кращі науково-дослідні установи, що займаються ефективним державно-приватним співробітництвом та партнерством, формуючи ядро дослідницьких та інноваційних «кластерів», включаючи «віртуальні дослідницькі спільноти», що в основному спеціалізується на міждисциплінарних дослідженнях і залучають критичну масу людських і фінансових ресурсів;

- ефективний обмін знаннями, зокрема між дослідниками і промисловістю, а також із 
громадськістю в цілому;

- добре скоординовані дослідницькі програми та пріоритети, включаючи значний обсяг спільних програм 3 міждержавним фінансуванням на європейському рівні 3 урахуванням загальних пріоритетів;

- широка відкритість Європейського дослідницького простору світу з особливим акцентом на сусідні країни і спрямованість на розв’язанні глобальних проблем з партнерами в Європі [8, с. 2-3].

Виконуючи програми досліджень, аспіранти можуть потребувати відвідування закордонних університетів і лабораторій для збору даних або виконання експериментів, не доступних у своїй країні. Але основні їх досягнення пов'язані з особистим, культурним i науковим зростанням, яке вони можуть отримати під впливом різних наукових і навчальних середовищ.

Основними позитивним факторами мобільності учених є можливість знаходження у висококваліфікованому робочому оточенні, у якому вони отримують якісні результати, та вільний доступ до ресурсів і наукового обладнання. Негативними чинниками мобільності зазвичай $є$ перешкоди, пов’язані з бюрократичними перепонами і труднощами в отриманні дозволу на роботу та візи на перебування. У зв'язку з цим у рамках ЄС були розроблені спеціальні норми для того, щоб полегшити в'їзд іноземних дослідників, які хочуть проводити наукові дослідження в рамках ЄС. Європейська комісія, наприклад, ввела Директиву 2005/71/ЕС від 12 жовтня 2005 року про особливу процедуру допуску громадян третіх країн 3 метою наукових досліджень [4] для регулювання процедури видачі спеціальних наукових віз.

Перепонами для мобільності аспірантів і молодих науковців є насамперед загроза втратити можливості із працевлаштування у своїй країні або рідному місті: такі люди вважають за краще залишатись у рідному університеті, навіть якщо він має більш низький рівень та надає менші можливості для саморозвитку. Тим не менше, проблеми, пов'язані 3 «витоком мізків», усе ще не вирішені: особливо це стосується країн, що розвиваються, у яких повернення талановитих дослідників до рідних країн після набуття досвіду мобільності $є$ проблематичним. Повернення мобільного дослідника означає, що його рідна країна отримає нові знання і його досвід, управлінські навички тощо, врешті-решт становлячись більш конкурентоспроможною: дослідження М. Бейна (Michel Beine), Ф. Док’€ (Fréderic Docquier) та Г. Рапопорт (Hillel Rapoport) показали, що подвоєння показника міграції висококваліфікованих фахівців забезпечує 5 \%-е збільшення валових капіталовкладень на душу корінного населення [3].

\section{Література}

1. Auriol L. Careers of Doctorate Holders: Analysis of Labour Market and Mobility Indicators / Laudeline Auriol, Max Misu, Rebecca A. Freeman. - Paris : OECD Publishing, 2013. 61 p. - (OECD Science, Technology and Industry Working, 2013/04). 2. Avveduto S. Mobility of $\mathrm{PhD}$ Students and Scientists / S. Avveduto // International Encyclopedia of Education. Third Edition / Editors-in-Chief Penelope Peterson, Eva Baker, Barry McGaw. - Oxford : Elsevier Academic Press, 2010. - Volume 4. - P. 286-293. 3. Beine M. Brain drain and human capital formation in developing countries: Winners and losers / Michel Beine, Fréderic Docquier and Hillel Rapoport // Economic Journal. - 2008. - Iss. 118. - P. 631-652. 4. Council Directive 2005/71/EC of 12 October 2005 on a specific procedure for admitting third-country nationals for the purposes of scientific // Official Journal of the European Union. - 2005. - Vol. 48. - 3 November. - P. 15-22.

5. Davis A. Children of bondage : the personality development of Negro youth in the urban South / 
Allison Davis, John Dollard. - Washington: American Council on Education, 1940.XXVIII+299 p. 6. Dumont J. C. Counting immigrants and expatriates in OECD countries: a new perspective [Electronic resource]/ Jean-Christophe Dumont, and Georges Lemaître; OECD, Directorate for Employment Labour and Social Affairs. - [Paris] : OECD, [2005]. - Access mode : http://www.oecd.org/migration/mig/ 33868740.pdf - ([OECD Social Employment and Migration Working Papers, N. 25]). 7. Emigration of Scientists from the United Kingdom : Report of a Committee Appointed by the Council of the Royal Society. - London : Royal Society, 1963. - 32 p.

8. Green Paper: The European Research Area: New Perspectives [Electronic resource]/ Commission of the European Communities. - Brussels, 2007. - 23 p. - Mode of access : http://ec.europa.eu/research/era/ pdf/era_gp_final_en.pdf 9. Knight J. Crossborder Education: An Analytical Framework for Program and Provider Mobility / Jane Knight// Higher Education: Handbook of Theory and Research. Volume XXI / Edited by John C. Smart. - Dordrecht : Springer, 2006. - P. 345-395. 10. Knight J. Higher Education Crossing Borders / J. Knight // International Encyclopedia of Education. Third Edition / Editors-in-Chief Penelope Peterson, Eva Baker, Barry McGaw. - Oxford : Elsevier - Academic Press, 2010. - Volume 4. - P. 507-513. 11. Ko E. The Washington Accord on Engineering Curriculum / E. Ko // International Encyclopedia of Education. Third Edition/ Editors-in-Chief Penelope Peterson, Eva Baker, Barry McGaw.- Oxford: Elsevier - Academic Press, 2010. - Volume 4. - P. 209-215. 12. Obi S. O. Related Services for Children with Special Needs / S. O. Obi // International Encyclopedia of Education. Third Edition / Editors-in-Chief Penelope Peterson, Eva Baker, Barry McGaw. - Oxford : Elsevier - Academic Press, 2010. - Volume 2. - P. 834-839. 13. Proceedings of the International Congress on Technology and Blindness : Volume III: Panel III, Sound recording and reproduction. Panel IV, Adapted and special purpose devices, 2d ed. / Edited by Leslie L. Clark. - New York : American Foundation for the Blind, 1963. - 384 p. 14. Wende M. van der. Internationalization of Higher Education / M. van der Wende // International Encyclopedia of Education. Third Edition / Editorsin-Chief Penelope Peterson, Eva Baker, Barry McGaw. - Oxford : Elsevier - Academic Press, 2010. - Volume 4. - Р. 540-545. 15. Велика Хартія Університетів [Електронний ресурс]. Болонья, 18 вересня 1988. - 2 с. - Режим доступу : http:/www.magna-charta.org/resources/ files/the-magna-charta/ukrainian 16. Стрюк М. I. Витоки мобільного навчання у країнах Європейського Союзу / Микола Стрюк // Педагогіка вищої та середньої школи : [зб. наук. праць] / ДВНЗ «Криворізький національний університет».- Кривий Ріг, 2013. Випуск 38. - С. 350-355.

УДК 37:004.588

Анна Томіліна

\section{МОЖЛИВОСТІ РОЗРОБОК ЕЛЕКТРОННИХ ОСВІТНІХ РЕСУРСІВ НА БАЗІ ЕЛЕКТРОННОЇ ПЛАТФОРМИ МООDLЕ ПІД ЧАС НАВЧАННЯ СТУДЕНТІВ IHОЗЕМНОÏ МОВИ}

Томіліна А. О. Можливості розробок електронних освітніх ресурсів на базі електронної платформи Moodle під час навчання студентів іноземної мови.

У статті розглядаються можливості створення електронних освітніх ресурсів на базі електронної платформи Moodle для студентів-філологів, що відповідають вимогам законодавчих нормативів України. Автор наводить приклади 3 власного досвіду створення електронних навчальних курсів у межах навчально-освітнього порталу Криворізького педагогічного інституту ДВНЗ «Криворізький національний університет». 